\title{
IMPLIKASI YURIDIS NIKAH SIRI DALAM PERSPEKTIF UNDANG-UNDANG NOMOR 1 TAHUN 1974 TENTANG PERKAWINAN
}

\author{
(Sebagai Upaya Menggugah Kesadaran Hukum Masyarakat)
}

\author{
Nunung Nugroho*
}

\begin{abstract}
In people's lives there is still a frequent way of marriage which is a violation of Law Undang-Undang No. l Tahun 1974, especially article 2 paragraph 2, namely: "Each marriage is recorded according to the applicable laws and regulations". The definition of violation in the law, known as siri marriage. In this case the law must be understood as a set of rules governing, controlling society. Law in this sense is not part of the community system, but control of the community system. Law in this sense is not part of the community system, but control of the community system. According to Gustav Radbruch law must contain three basic values, namely: 1. Value of justice (philosophical aspect). The validity of the law is justified on the basis of human philosophical beliefs. 2. Value of certainty (juridical aspect). The law is enforced because it is determined by the state (gemeenschap), namely by the government and the people's representative council. 3. Value of benefits (sociological aspects). The validity of the law is due to social reality (society as a whole). In a sociological and philosophical view, siri marriage is relatively acceptable to the community, but judicially cannot be justified because it will have an impact on the low legal awareness of the community. Marriage recording does not determine the validity of a marriage, but only states that the marriage event actually happened, so it is merely administrative. Thus, the marriage is legitimate because it is carried out in accordance with religious law but has a weakness, namely the absence of a recording as referred to in article 2 paragraph 2 of Undang-Undang No. l Tahun 1974. In reality the registration of marriages brought more good than bad in living in a society, so carrying out the registration of the marriage would be in line and not in conflict with religious norms.
\end{abstract}

Keywords: Juridical Implications of Siri Marriage, Perspective of Undang-Undang Nomor 1 Tahun 1974

\section{PENDAHULUAN}

Pada jaman primitif bentuk-bentuk perkawinan yang ada tidak dapat diketahui secara jelas akan tetapi seiring dengan perkembangan zaman akhirnya dapat diketahui juga bentuk-bentuknya. Perkawinan berkembang dari perkawinan

* Nunung Nugroho adalah Pengajar di Fakultas Hukum UNTAG Semarang, Bidang Kajian Hukum Perdata, UNTAG Semarang dapat di hubungi melalui email : nugrohobsn@yahoo. com yang bebas merdeka, kemudian perkawinan jual-beli, perkawinan rampasan dan selanjutnya setelah timbul agama perkawinan diatur dengan tata cara dan norma tertentu, termasuk norma agama. Nilai-nilai kehidupan sosial sangat mempengaruhi norma hukum dalam kehidupan masyarakata, termasuk pada perkawinan itu sendiri yang meliputi syarat-syarat perkawinan, pelaksanaannya serta kelanjutan kehidupan keluarga termasuk dalam kelanjutan kehidupan anak keturunan yang lahir akibat suatu 
perkawinan. Sehubungan dengan hal tersebut, maka tentang perkawinan bagi yang beragama Islam telah ada unifikasi hukum yaitu Undang-Undang No. 1 Tahun 1974 tentang perkawinan dan sebagai peraturan pelaksananya adalah Peraturan Pemerintah No.9 Tahun 1975.

Dalam kehidupan masyarakat masih sering terjadi cara perkawinan yang merupakan pelanggaran terhadap UndangUndang No. 1 Tahun 1974 khususnya pasal 2 ayat 2 yaitu : "Tiap-tiap perkawinan dicatat menurut peraturan perundangundangan yang berlaku”. Adapun yang dimaksud dengan pelanggaran dalam undang-undang tersebut yang dikenal dengan istilah nikah siri. Orang-orang yang menempuh dengan cara perkawinan dimaksud biasanya menggunakan berbagai macam alasan sebagai berikut :

1. Ada yang terpaksa harus kawin karena kekasihnya sudah berbadan dua sedangkan kedua orang tua calon mempelai wanita tidak menyetujuinya.

2. Ada alasan karena sebagai terobosan untuk mengatasi bahwa dia merupakan Pegawai Negeri Sipil yang dilarang mempunyai istri lebih dari satu tanpa alasan tertentu.

3. Ada yang menghindari prosedur tertentu demi nilai praktisnya

4. Ada yang menghindari perzinahan, karena nikah siri sudah sesuai dengan hukum agama. Hal ini berkaitan dengan bunyi pasal 2 ayat (1) Undang-Undang No. 1 Tahun 1974 yang menyatakan bahwa perkawinan adalah sah apabila dilakukan menurut hukum masingmasing agamanya dan kepercayaannya, dan itu merupakan salah satu perwujudan dari nilai-nilai Pancasila sebagai falsalah negara. Mengingat bahwa Pancasila sebagai landasan hukum nasional yang responsif mengemban dua fungsi, yakni fungsi ekspresif dan fungsi instrumental. Menurut Arief Sidharta fungsi ekspresif mengungkapkan pandangan hidup, nilai-nilai kebudayaan dan keadilan. Sedangkan fungsi instrumental, hukum nasional sebagai sarana menciptakan dan memelihara ketertiban, stabilitas dan prediktabilitas, sarana untuk melestarikan budaya-budaya dan mewujudkan keadilan, sarana pendidik an serta pengabdian masyarakat dan sarana pembaruan masyarakat. ${ }^{1}$ Dalam hubungan ini, perlu diketahui bahwa perkawinan tidak lagi dilihat hanya dalam hubungan perdata, sebab perkawinan mempunyai hubungan yang erat sekali dengan agama atau kerohanian, sehingga tidak ada perkawinan diluar hukum masingmasing agamanya dan kepercayaan nya. ${ }^{2}$

Demikian juga akibat dari nikah siri banyak menimbulkan dampak negatifnya, misalnya perkawinan dapat putus tanpa ada sebab yang jelas karena alasan bosan saja mereka dapat melakukan perceraian, juga tanggung jawab dalam keluarga sangat kurang karena tidak adanya suatu pencatatan secara resmi yang mengikat kedua belah pihak. Demikian juga anakanak dari perkawinan tersebut tidak mempunyai hubungan hukum dengan kedua orang tuanya. Meskipun demikian, masih ditempuh juga cara yang banyak menimbulkan kerugian itu.

Nikah siri sebetulnya secara yuridis tidak menjamin kepastian hukum bagi kedua belah pihak dan keturunannya, secara sosiologis tidak ada keterbukaan di dalam keluarga, lingkungan dan masyarakat, demikian juga secara filosofis ada rasa ketidakadilan antara suami istri maupun anak keturunannya selama dalam hubungan perkawinan maupun putusnya perkawinan, akibat perceraian maupun

1 Teguh Prasetyo dan Arie Purnomosidi, Membangun Hukum Berdasarkan Pancasila, Nusa Media, Bandung, 2015, hal.161-162

2 Hilman Hadikusuma, Hukum Adat Dalam Yurisprudensi, PT. Citra Aditya Bakti, Bandung, 1997, hal.86 
kematian salah satu pihak ataupun keduanya.

Tujuan perkawinan itu sendiri ada beberapa unsur antara lain :

1. Membentuk Keluarga Yang Bahagia.

Kebahagiaan keluarga merupakan citacita yang harus dapat dicapai dalam suatu perkawinan untuk masing-masing pihak harus dapat melaksanakan kewajiban dan saling menghormati hakhak yang digariskan dalam UndangUndang Perkawinan yang berlaku.

2. Kekal

Suatu perkawinan pada prinsipnya harus berlangsung selama mungkin, baik itu dikehendaki oleh yang bersangkutan secara langsung yaitu suami, anak keturunannya maupun dikehendaki oleh masyarakat. Untuk itu maka Undang-Undang No.l Tahun 1974 memuat ketentuan-ketentuan alasan putusnya perkawinan sebagai cara untuk memperkuat status perkawinan dan mempersukar terjadinya perceraian.

3. Ketuhanan Yang Maha Esa.

Untuk mencapai kelurga yang bahagia dan kekal, perkawinan harus berdasarkan atas Ketuhanan Yang Maha Esa, sesuai dengan prinsip-prinsip yang terkandung didalam PerundangUndangan Perkawinan No.1 Tahun 1974 bahwa perkawinan dianggap sah apabila dilakukan menurut hukum agama dan kepercayaan dari masingmasing pihak yang akan melangsung kan perkawinan. Jadi jelaslah bahwa perkawinan harus diridhoi oleh Allah SWT, sebab perkawinan mempunyai tujuan kebahagia dunia dan akhirat.

Perkawinan selain dilaksanakan sesuai dengan masing-masing agama dan kepercayaan maka perkawinan hendaklah dicatatkan pada Kantor Urusan Agama (KUA) yang merupakan lembaga yang berkompeten untuk melaksanakan pencatatan nikah, talak, rujuk dan cerai yang berkedudukan diwilayah tempat tinggal suami istri. ${ }^{3}$ Sebaliknya perkawinan yang tidak didaftarkan atau dicatatkan akan mendapat kesulitan dalam hal pembuktian telah adanya perkawinan, karena secara hukum pasangan suami istri itu tidak dianggap telah menikah, sebab tidak pernah mendaftakan perkawinannya. ${ }^{4}$

Semuanya itu tujuannya untuk mencegah preseden tentang nikah siri yang selama ini dilaksanakan tanpa melalui pencatatan yang sesuai dengan peraturan perundang-undangan. Sehingga dapat tereliminir menjadi pernikahan yang sesuai dengan peraturan perundang-undangan yang mengandung kepastian hukum, keterbukaan serta terpenuhinya rasa keadilan bagi kedua belah pihak beserta anak-anak keturunannya.

Berdasarkan latar belakang dimaksud, mendorong penulis untuk mengetahui dan memperdalam lebih jauh tentang hal-hal yang berhubungan dengan "Implikasi Yuridis Nikah Siri Dalam PerspektifUndang-Undang Nomor 1 Tahun 1974 Tentang Perkawinan Sebagai Upaya Menggugah Kesadaran Hukum Masyarakat"

\section{Pembahasan}

Manusia di dalam masyarakat memerlukan perlindungan kepentingan. Perlindungan kepentingan itu tercapai dengan terdapatnya pedoman atau peraturan hidup yang menentukan bagaimana manusia harus bertingkah laku dalam masyarakat agar tidak merugikan orang lain dan dirinya sendiri. Pedoman, patokan atau ukuran untuk berperilaku atau bersikap dalam kehidupan bersama ini disebut norma atau kaidah sosial.

Kaidah sosial pada hakikatnya merupakan perumusan suatu pandangan mengenai perilaku atau sikap yang seyogyanya dilakukan atau yang seyogyanya tidak dilakukan, yang dilarang

3 Hilman Hadikusuma, Ibid, hal.27 
dijalankan atau yang dianjurkan untuk dijalankan. Dengan kaidah sosial ini hendak dicegah gangguan-gangguan kepentingan manusia, akan dapat dihindar kan bentrokan antar kepentingan, akan diharapkan terlindungi kepentingankepentingan manusia. Kaidah sosial ini ada yang berbentuk tertulis ada pula yang lisan yang merupakan kebiasaan yang diteruskan dari generasi ke generasi. ${ }^{5}$

Kaidah sosial yang tertulis wujud nya berupa peraturan perundang-undangan atau lebih dikenal dengan nama norma hukum/hukum (menurut pengertian paham legisme).

Hukum adalah tata aturan (order) sebagai suatu sistem aturan aturan (rules) tentang perilaku manusia. Dengan demikian hukum tidak menunjuk pada satu aturan tunggal (rule), tetapi seperangkat aturan (rules) yang memiliki suatu kesatuan sehingga dapat dipahami sebagai suatu sistem. Konsekuensinya, adalah tidak mungkin memahami hukum jika hanya memperhatikan satu aturan saja.

Disamping itu hukum adalah suatu tata aturan tentang perilaku manusia tidak berarti bahwa tata hukum (legal order) hanya terkait dengan perilaku manusia, tetapi juga dengan kondisi tertentu yang terkait dengan perilaku manusia. Setiap aturan hukum mengharuskan manusia melakukan tindakan tertentu atau tidak melakukan tindakan tertentu dalam kondisi tertentu. Kondisi tersebut tidak harus berupa tindakan manusia, tetapi dapat juga berupa suatu kondisi. Namun, kondisi tersebut baru dapat masuk dalam suatu aturan jika terkait dengan tindakan manusia, baik sebagai kondisi atau sebagai akibat. ${ }^{6}$ Seperti diketahui norma hukum yang ditetapkan oleh otoritas pembuat

5 Sudikno Mertokusumo, Mengenal Hukum, (Suatu Pengantar), Yogyakarta, Liberty, 2014, hal.1-5

6 Jimly Assiddiqie, dan Ali Safa'at, Teori Hans Kelsen Tentang Hukum, Konstitusi Press, Jakarta, 2012, hal.13 hukum adalah peskriptif, sedangkan aturan hukum yang diformulasikan oleh ilmu hukum adalah deskriptif. ${ }^{7}$

Salah satu fungsi penting dari norma hukum yang ditetapkan oleh otoritas pembuat hukum/peraturan adalah sebagai penuntun perilaku. Dalam kondisi bagaimana orang-orang menggunakan atau bereaksi terhadap peraturan hukum? dalam kondisi apa mereka menolak, menyalah gunakan, atau mengabaikan hukum? Sebab tindakan hukum (legal acts) memiliki banyak bentuk. Keputusan apapun yang dibuat oleh otoritas hukum, peraturan baru apapun yang menegakkan peraturan lama adalah tindakan hukum. Suatu tindakan hukum pasti memiliki dampak, ketika hal itu secara kausal berkaitan dengan perilaku seseorang. Tindakan hukum dikatakan "efektif" ketika perilaku bergerak ke arah yang dikehendaki, ketika subyek patuh atau menurut. Banyak tindakan hukum tidak efektif karena orang-orang mengabaikan atau melanggar ketentuan. Ketidakpatuhan secara sengaja mungkin menjadi bagian sebuah sistem perilaku, yang bagaimana pun juga bertalian dengan sistem hukumnya. Demikian pula dampak tindakan hukum konkrit, dengan kata lain merupakan sesuatu yang lebih sekedar kepatuhan, sebab dampak adalah efek total suatu tindakan hukum terhadap perilaku, entah itu positif atau negatif. ${ }^{8}$

Hukum pada umumnya dapat diartikan sebagai dokumen antropologis (hukum adalah dokumen antropologis besar) karena penetapan hukum benarbenar mencerminkan upaya manusia sesuai dengan kondisi yang relevan untuk mengatur bersama-sama untuk mendapat kan kehidupan yang lebih baik. Manusia dalam perjalanan untuk menyesuaikan diri dengan kehidupan yang lebih baik adalah sebuah perjalanan yang tak pernah berakhir.

7 Jimly Assiddiqie, dan Ali Safa'at, Ibid, hal.43

8 Lawrence M. Friedman, Sistem Hukum, Perspektif Ilmu Sosial, Nusa Media, Bandung, 2015, hal.61-62 
Selalu ada upaya perbaikan terus-menerus sesuai dengan perkembangan peradaban dan tatanan sosial. Oleh karena itu benar untuk mengatakan bahwa hukum dan pengembangan ilmu hukum tidak akan lepas dari tatanan sosial. Dengan kata lain, mengerti hukum harus dimulai dengan memahami tatanan sosial masyarakat. tatanan sosial sebenarnya merupakan cara orang berpikir dari lingkungan sosial mereka, yang selalu terikat oleh ruang dan waktu. Perkembangan tatanan hukum seperti itu akan mencerminkan semangat zaman, semangat dari tatanan sosial. ${ }^{9}$

Dewasa ini tumbuh kesadaran bahwa apa yang disebut hukum memiliki peran tidak hanya untuk menjamin ketepatan untuk selalu menjaga dan dijaminnya prediktabilitas perilaku, tetapi juga berfungsi untuk kehidupan masyarakat langsung dalam rangka mewujudkan pola perilaku tertentu. Dalam hubungan ini, mulai tumbuh kesadaran bahwa apa yang disebut hukum, bahwa hukum positif itu belum tentu yang dikeluarkan oleh penguasa yang sah dari aturan tertulis yang nyata. Pola hubungan yang telah mantap dan terus dilakukan di masyarakat dan diterima sebagai sesuatu yang harus dilakukan, sebenarnya apa yang disebut hukum. Jadi hukum adalah sumber order (keteraturan) yang berasal dari fakta atau pengalaman hidup dari masyarakat itu sendiri. ${ }^{10}$

Berbicara tentang hukum sama dengan berbicara tentang aturan hukum yang harus berlaku dan yang mungkin tidak dinyatakan berlaku, untuk memecahkan masalah-masalah konkret di masyarakat. Dalam hal ini hukum harus dipahami sebagai seperangkat aturan yang mengatur, mengontrol masyarakat. Hukum dalam arti ini bukan bagian dari sistem masyarakat, tapi kontrol dari sistem masyarakat. ${ }^{11}$

9 ....... dari Modernisme ke Post-Modernisme Pengaruhnya Terhadap Ilmu Hukum, hal. 1

10 Ibid, hal.13

11 Ibid, hal.22
Menurut Thomas Hobbes disebut kan bahwa manusia sesungguhnya merupakan serigala bagi manusia yang lain (homo homini lupus) ${ }^{12}$ dan oleh karena itu di dalam suatu kehidupan harus adanya tatanan yang wajib dipatuhi oleh setiap manusia yaitu dari tingkat yang rendah yang dikenal dengan nama norma. Adapun yang dimaksud dengan norma yaitu suatu sarana yang dipakai oleh masyarakatnya untuk menertibkan, menuntut dan mengarahkan tingkah laku anggota masyarakat dalam hubungannya satu sama lain $^{13}$, sebagaimana diketahui, di dalam kehidupan manusia bermasyarakat terdapat beberapa macam norma yaitu:

1. Norma agama adalah sistem aturan yang diperoleh manusia berdasarkan ajaran agama yang dianutnya.

2. Norma moral adalah sistem aturan yang berlaku bagi manusia yang bersumber dari setiap hati manusia atau hati nurani yang bekerja atas dasar kesadaran setiap manusia terhadap sekelilingnya.

3. Norma etika atau kesopanan adalah sistem aturan hidup manusia bersumber dari kesepakatan yang diciptakan oleh dan dalam suatu komunitas masyarakat pada wilayah tertentu.

4. Norma hukum adalah sistem aturan yang diciptakan oleh lembaga kenegaraan yang ditunjuk melalui mekanisme tertentu.

Untuk menjalankan fungsi norma tersebut di atas, maka ia harus memiliki kekuatan yang bersifat memaksa, dan paksaan ini tertuju kepada para anggota masyarakat dengan tujuan untuk mematuhi nya, contoh pada:

1. Norma agama : Para anggota masyarakat akan mematuhi norma agama karena takut hila berbuat salah (dosa) akan mendapatkan sanksi oleh

12 Adji Samekto, Pergeseran Pemikiran Hukum Dari Era Yunani Menuju Postmodernisme, Jakarta: Konstitusi Press, 2015, hal. 7

13 Satjipto Rahardjo., Ilmu Hukum, Bandung: Citra Aditya Bakti, 2000, hal. 27. 
Tuhan yang berupa siksa api neraka.

2. Norma moral: Para anggota masyarakat akan mematuhi norma moral. karena setiap hati manusia akan mengatakan bila berbuat buruk akan mendapatkan sanksi yang berupa malu.

3. Norma etika : Para anggota masyarakat akan mematuhi norma etika karena takut bila berbuat tercela akan mendapatkan sanksi yang berupa dikucilkan oleh masyarakat.

4. Norma hukum : Para anggota masyarakat akan mematuhi norma hukum karena takut hila melanggarnya akan mendapatkan sanksi oleh penguasa yang berupa nestapa.

Menurut Hans Kelsen disebutkan, bahwa norma-norma tersebut akan menjadi mengikat para anggota masyarakat apabila norma-norma tersebut dikehendaki menjadi hukum, dan di dalam teorinya yang sangat terkenal yaitu "teori hukum murni/ pure theory of law / reine rechtslehre" disebutkan bahwa hukum ditaati bukan karena dinilai baik dan adil, tetapi karena hukum itu telah ditulis dan disahkan penguasa. ${ }^{14}$ Yang menjadi pertanyaan siapa itu penguasa, menurut Steve Agusta mengatakan bahwa "teori hukum positif' yang dikemukakan oleh John Austin terinspirasi dari Kaisar Justinianus I yang mengungkapkan bahwa apa yang menyenangkan Kaisar memiliki kekuatan hukum, dan oleh karena itu hukum adalah apa yang dikendaki oleh penguasa, dan hal ini dilatar belakangi oleh suatu kepercaya an masyarakat pada waktu itu yang mempercayai bahwa raja sebagai wakil Tuhan, maka raja dipandang tidak pernah bertindak salah, dan oleh karena itu titah raja adalah perintah yang harus ditaati tanpa opsi apapun oleh rakyatnya. ${ }^{15}$ Dengan demikian yang

14 Adji Samekto., Op Cit, hal.80

15 Adji Samekto., Ibid, hal 75-76. dimaksud sebagai penguasa waktu itu adalah raja.

Sehubungan dengan hal tersebut, revolusi Perancis telah melahirkan asas demokrasi yang mana penguasa bukanlah di tangan raja tetapi sekarang kekuasaan berada di tangan rakyat, begitu pula dalam hal pembuat hukum yang mana dahulu pembuatnya ada ditangan raja dan sekarang berada di tangan rakyat yang didelegasikan kepada pemerintah dan parlemen sebagai kekuasaan tertinggi dalam mengatur negara, dan dengan demikian hukum yang dibuat oleh otoritas yang tertinggi dengan sendirinya dapat diterima sebagai hukum yang berlaku ditaati masyarakat, menjangkau siapapun tanpa kecuali. Dari uraian inilah yang menjadi landasan positivisme hukum, karena Hans Kelsen mengatakan bahwa positivisme hukum menganggap pembahasan moral atau nilainlai telah selesai atau final manakala sudah sampai pada pembentukan hukum positif.

Menurut Gustav Radbruch dikata kan bahwa hukum harus memuat tiga nilai dasar yaitu sebagai berikut ${ }^{16}$ :

1. Nilai keadilan (aspek filosofis).

Berlakunya hukum dibenarkan atas dasar keyakinan filsafati manusia.

2. Nilai kepastian (aspek yuridis).

Berlakunya hukum karena ditetapkan oleh negara (gemeenschap) yaitu oleh pemerintah dan dewan perwakilan rakyat.

3. Nilai kemanfaatan(aspek sosiologis).

Berlakunya hukum karena dalam kenyataan sosial (masyarakat secara keseluruhan).

Berkaitan dengan hukum Negara yang sifatnya mengandung kepastian hukum, maka dalam konteks penelitian ini kita perlu menengok sejenak sebagaian dari isi Undang-Undang No.1 Tahun 1974 tentang perkawinan. Pengertian perkawinan menurut Undang-Undang No.1 Tahun 1974 terdapat dalam pasal 1 yang

16 Notohamidjojo., Soal-Soal Pokok Filasafat Hukum, Jakarta:PB. Kristen, 1975, hal.30 
berbunyi sebagai berikut : Perkawinan adalah ikatan lahir batin antara seorang pria dengan seorang wanita sebagai suami istri dengan tujuan membentuk keluarga atau rumah tangga yang bahagia dan kekal berdasarkan Ketuhanan Yang Masa Esa. Dari pengertian perkawinan diatas dapat dilihat adanya empat unsur, yaitu :

a. Ikatan lahir batin

b. Seorang pria dan wanita

c. Rumah tangga yang bahagia dan kekal

d. Berdasarkan Ketuhanan Yang Maha $\mathrm{Esa}^{17}$

Dalam Pasal 3 Kompilasi Hukum Islam perkawinan bertujuan untuk mewujudkan kehidupan rumah tangga yang sakinah, mawaddah dan rahma. Dari rumusan tersebut diatas, filosofis Islam Imam Ghasali membagi tujuan dan faedah perkawinan menjadi lima, yaitu : ${ }^{18}$

a. Memperoleh keturunan yang sah yang akan melangsungkan keturunan serta perkembangan suku-suku bangsa manusia.

b. Memenuhi tuntutan naluri hidup manusia.

c. Memelihara marusia dari kejahatan dan kerusakan.

d. Membentuk dan mengatur rumah tangga yang menjadi dasar pertama dari masyarakat yang besar, atas dasar kecintaan dan kasih yang halal dan memperbesar tanggung jawab.

e. Menumbuhkan akifitas dalam berusaha mencari nafkah yang halal dan memperbesar rasa tanggung jawab.

Tujuan perkawinan, pertama yaitu memperoleh keturunan yang sah adalah merupakan tujuan yang pokok dari perkawinan itu sendiri. Memperoleh keturunan dalam perkawinan bagi penghidupan manusia mengandung dua segi kepentingan, yaitu untuk diri pribadi dan umum. Setiap perkawinan tentu

17 Wirjono Projodikoro, Hukum Perkawinan Di Indonesia, Sumur, Bandung, 1990, hal.45

18 Soemiyati, Hukum Perkawinan Islam Dan Undang-Undang Perkawinan, Ed.1, Cetakan 2, Liberty, Yogyakarta, 1989, hal.12-13 mempunyai keinginan untuk memperoleh keturunan atau anak, karena anak itulah yang akan menyambung keturunan yang akan berkembang untuk meramaikan dan memakmurkan dunia.

Kedua adalah untuk memenuhi tuntutan lahiriah. Tuhan menciptakan jenis kelamin yang berbeda, yaitu laki-laki dan perempuan sudah menjadi kudrat antara kedua jenis itu saling mengadung daya tarik, dilihat dari sudut biologis daya tarik adalah rasa saling membutuhkan. Dengan perkawinan memenuhi tuntutan tabiat kemanusiaan itu dapat tersalurkan dengan sah. Andai kata tidak melalui perkawinan maka manusia akan banyak melakukan perbuatan-perbuatan yang menimbulkan hal-hal yang tidak baik dalam masyarakat dimana dia berada.

Ketiga ialah menjaga manusia dari kerusakan dan kejahatan, agar manusia tidak berbuat jahat, dan tidak rusak karena pengaruh dari hawa nafsunya saja. Biasanya baik laki-laki atau perempuan akan mencari jalan yang halal. Pengaruh hawa nafsu itu adalah demikian besarnya sehingga kadang-kadang manusia sampai lupa untuk menilai mana yang baik dan mana yang buruk. Untuk menghindarkan diri dari perbuatan yang tidak baik yang akan menuju kejahatan kerusakan itu maka sebaiknya manusia melakukan perkawinan.

Keempat ialah membentuk dan mengatur rumah tangga yang merupakan basis pertama dari masyarakat atas dasar kecintaan yang besar untuk kecintaan dan kasih sayang. Ikatan perkawinan kalau dibandingkan dengan ikatan-ikatan yang lain yang biasanya dilaksanakan didalam hidup bennasyarakat merupakan ikatan yang paling tegas, suci dan kuat. Seperti diketahui bahwa melaksanakan perkawinan tidak ada ikatan apapun. Satu-satunya alat untuk memperoleh ikatan, perkawinan adalah rasa cinta, kasih sayang antara lakilaki dan perempuan secara timbal balik. Atas dasar cinta kasih sayang inilah, kedua belah pihak yang akan melakukan ikatan 
perkawinan berusaha membentuk rumah tangga yang bahagia kemudian lahir anak, selanjutnya bertambah luas jadi keluarga dan seterusnya, sehingga tersusun masyarakat yang besar.

Kelima adalah menumbuhkan akifitas dalam berusaha mencari nafkah yang halar dan memperbesar rasa tanggung jawab. Sebelum melaksanakan perkawinan pada umumnya para pemuda maupun pemudi tidak memikirkan soal penghidup an, karena segala keperluan masih ditanggung orang tuanya masing-masing, tetapi setelah berumah tangga mereka mulai menyadari akan tanggungjawab di dalam rumah tangganya. Suami sebagai kepala keluarga mulai memikirkan bagaimana cara mengatur kehidupan rumah tangga. Hal itu akan mengakibatkan berubahnya aktifitas kedua belah pihak, si suami berusaha sungggh-sungguh dalam mencari rezeki, sedangkan istri lebih giat berusaha mencari jalan bagaimana menyelenggarakan rumah tangga yang damai dan bahagia. Kelima tujuan dan faedah sesuai dengan yang diharapkan.

\section{Penutup}

Dalam pandangan sosiologis maupun filosofis, nikah siri relative dapat diterima oleh masyarakat, tetapi secara yuridis tidak dapat dibenarkan karena akan berdampak pada rendahnya kesadaran hukum masyarakat. Pencatatan perkawinan tidak menentukan sah tidaknya suatu perkawinan, tetapi hanya menyatakan bahwa peristiwa perkawinan benar-benar terjadi, jadi semata-mata hanya bersifat administratif. Dengan demikian dapat dijelaskan bahwa nikah siri adalah sah adanya karena dilakukan sesuai dengan hukum agama tetapi mempunyai kelemahan yaitu tidak adanya suatu pencatatan seperti yang dimaksud dalam pasal 2 ayat 2 Undang-Undang No. 1 Tahun 1974. Dalam kenyataannya pencatatan perkawinan lebih banyak mendatangkan kebaikan dari pada keburukan di dalam hidup bermasyarakat, maka melaksanakan pencatatan perkawinan ini akan sejalan dan tidak bertentangan dengan norma agama.

\section{Daftar Pustaka}

Adji Samekto., Pergeseran Pemikiran Hukum Dari Era Yunani Menuju Postmodernisme, Jakarta: Konstitusi Press, 2015

Hilman Hadikusuma, Hukum Adat Dalam Yurisprudensi, PT. Citra Aditya Bakti, Bandung, 1997

Jimly Assiddiqie, dan Ali Safa'at, Teori Hans Kelsen Tentang Hukum, Konstitusi Press, Jakarta, 2012

Lawrence M. Friedman, Sistem Hukum, Perspektif Ilmu Sosial, Nusa Media, Bandung, 2015

Notohamidjojo., Soal-Soal Pokok Filasafat Hukum, Jakarta: PB. Kristen, 1975

Soemiyati, Hukum Perkawinan Islam Dan Undang-Undang Perkawinan, Ed.1, Cetakan 2, Liberty, Yogyakarta, 1989

Sudikno Mertokusumo, Mengenal Hukum, (Suatu Pengantar), Yogyakarta, Liberty, 2014

Satjipto Rahardjo., Ilmu Hukum, Bandung: Citra Aditya Bakti, 2000

Teguh Prasetyo dan Arie Purnomosidi, Membangun Hukum Berdasarkan Pancasila, Nusa Media, Bandung, 2015

Wirjono Projodikoro, Hukum Perkawinan Di Indonesia, Sumur, Bandung, 1990

Undang-Undang No. 1 Tahun 1974 Tentang Perkawinan.

........., Dari Modernisme ke PostModernisme Pengaruhnya Terhadap Ilmu Hukum 